\title{
Evaluation of periphyton quantity on different natural substrates in Earthen lined pond
}

\author{
A. Anix Vivek Santhiya*, S. Athithan, B. Ahilan, J. Stephen Sampath kumar and \\ A. Srinivasan \\ Fisheries College and Research Institute, Tamil Nadu Fisheries University, Tharuvaikulam-628105, (Thoothukudi) \\ INDIA \\ *Corresponding author. E-mail: santhiyafcri@gmail.com \\ Received: November 11, 2016; Revised received: February 22, 2017; Accepted: August 8, 2017
}

\begin{abstract}
Experiments were conducted in outdoor earthen lined pond to study periphyton quantity on three types of natural substrates such as split bamboo pole, coconut coir and coconut shell, which was placed inside the earthen lined pond filled with seawater for duration of 45 days. Observations were made in every $15^{\text {th }}$ day for growth of periphyton both qualitatively and quantitatively on the three natural substrates and physico-chemical properties of selected pond water such as transparency, water temperature, salinity, $\mathrm{pH}$, Dissolved oxygen, $\mathrm{Ammonia}\left(\mathrm{NH}_{3}-\mathrm{N}\right)$, Nitrite $\left(\mathrm{NO}_{2}-\mathrm{N}\right)$, Nitrate $\left(\mathrm{NO}_{3}-\mathrm{N}\right)$, BOD and Chlorophyll ' $a$ ' were recorded during periphyton samplings. The periphyton quantity $\left(34562 \pm 671\right.$ cells $\left./ \mathrm{cm}^{2}\right)$ observed for coconut coir was higher than the split bamboo pole $(33104 \pm 810$ cells $\left./ \mathrm{cm}^{2}\right)$, and coconut shell $\left(21194 \pm 872\right.$ cells $\left./ \mathrm{cm}^{2}\right)$ in the final day of the experiment. One way ANOVA of the data collected clearly affirmed that significant differences were observed $(P<0.05)$ in periphyton quantity among the three substrates tested. A total 16 phyto-periphytic microalgae (Bacillariophyceae -10 types, Dinophyceae -4 types and Cyanophyceae - 2 types) and 10 Zoo-periphyton (Copepod- 4 types, Meroplankton - 4 types and Tintinnidae -2 types) were recorded from these three substrates. Among the different phyto-periphytic microalgae, Bacillariophyceae group were found to be more (Split bamboo pole $-72 \%$, Coconut coir $-73 \%$ and Coconut shell $71 \%$ ) on three substrates studied. Further, coconut coir was found to be best substrate than split bamboo pole and coconut shell, which can be utilized by fin and shellfishes as natural food.
\end{abstract}

Keywords: Earthern lined pond, Natural food, Natural substrates, Periphyton quantity and quality

\section{INTRODUCTION}

The inefficient utilization of high amounts of costly feed is an important economic problem for intensive aquaculture. Additionally, the accumulation of food residues and metabolites within ponds causes degradation of sediments and water quality, requiring increasing rates of water exchange at additional costs (Avnimelech et al., 2008).To minimize costs, little attention was given to the periphyton-based food web. Periphyton has become an universally accepted expression for all organisms attached to a submerged substrate. In a recent report, periphyton was found to induce Labeo rohita to feed on an area densely packed with plankton near to substrate surface, explaining a kind of synergistic effect on feeding behaviour of fish on plankton even though the fish is not purely periphytophagous (Saikia et al., 2013). Some workers have compared the natural and artificial substrates for periphyton growth and found more periphytic growth on the natural substrates (Amisah et al., 2008; Keshavanath et al., 2012; Dutta et al., 2013). For the advantage of the substrates on shrimp growth, different authors carried out experiments from various aspects and obtained different results and provided different explanation including improvement of the water quality, addition of the natural food supplement, limitation of pathogenic bacteria reproduce, provide refuge for shrimp to escape any negative behavioural interactions and adding living space (Burford et al., 2004; Preto et al., 2005; Arnold et al., 2006; Zarain-Herzberg et al., 2006; Ballester et al., 2007).

The aim of the present work was to i) estimate the quantity and quality of periphyton grown on natural substrates of three locally available natural materials in the absence of fish and ii) determine the effects of substrates for periphyton on water quality for periphytonbased aquaculture system.

\section{MATERIALS AND METHODS}

The outdoor experiments were carried out in 2 lined ponds, each having water spread area of $30 \mathrm{~m}^{2}$ (Fig. 1). The ponds were well exposed to sun light and having water supply facilities. The water depth was maintained as $1.2 \mathrm{~m}$ over the study period. The experiment was carried out in duplicate with different natural materials for periphytic growth on them. 


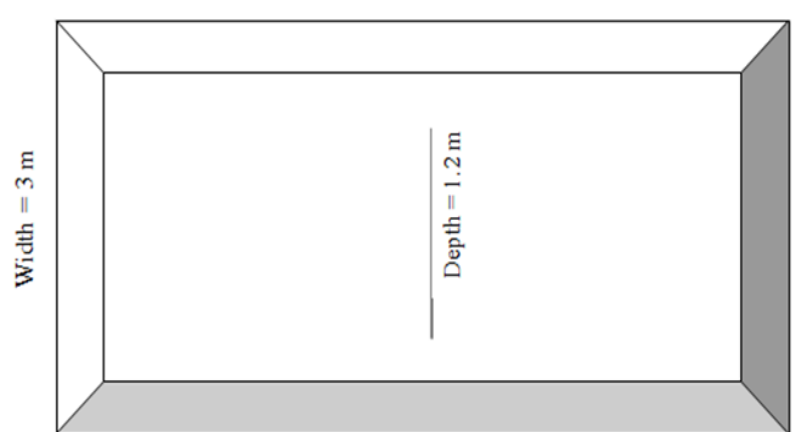

Fig. 1. Layout of earthen lined pond.

Three different types of natural materials such as split bamboo pole, coconut coir and coconut shell were used for periphyton growth. These natural substrate materials were collected locally. Ponds were drained and renovated and all other undesirable aquatic weeds and organisms were removed. All the substrates were driven vertically into the same pond to maintain the same environment. 5 Split bamboo poles $(1.5 \mathrm{~m}$ total length / $1.20 \mathrm{~m}$ Exposed length / $0.3 \mathrm{~m}$ Free Board) as substrate were used. These bamboo poles were tied in nylon ropes $(5 \mathrm{~mm})$ and vertically immersed in the experimental ponds. The space between each Split bamboo pole was $10 \mathrm{~cm} .5$ coconut coir $(1.3 \mathrm{~m}$ total length / $1.20 \mathrm{~m}$ Exposed length / Length $=10 \mathrm{~m} / 0.1 \mathrm{~m}$ Free Board) as substrate were used. These coconut coir were tied in nylon ropes $(5 \mathrm{~mm})$ and vertically immersed in the experimental ponds. The space between each coconut coir given was $10 \mathrm{~cm}$. In the case of coconut shell, $1.3 \mathrm{~m}$ length nylon twine was taken and 5 coconut shells were arranged in each line and hanged vertically. These five nylon twines were tied in nylon ropes and immersed vertically in the experimental ponds ( 5 coconut shell $\mathrm{x} 5$ nylon twines). The mean diameter of the bamboo pole, coconut coir and coconut shell were $6.2 \mathrm{~cm}, 2.6 \mathrm{~cm}$ and $11.4 \mathrm{~cm}$ respectively. After the substrates were installed, the ponds were filled with sea water. The water depth in each pond was monitored daily at $1.20 \mathrm{~m}$ and maintained by pumping sea water to replace losses at weekly intervals. Quicklime $(\mathrm{CaO})$ was applied to the pond at the rate of $250 \mathrm{~kg} /$ ha (Azim et al., 2003). Three days after liming, ponds were fertilized with cow dung at the rate of $1,500 \mathrm{~kg} / \mathrm{ha}$. The application of cow dung was continued once in 10 days at a same dosage rate over the study period. The average diffuse radiation near the substrate in the pond water was $49.5 \mathrm{~cm}$.

Periphyton samples were collected on $15^{\text {th }}, 30^{\text {th }}$ and $45^{\text {th }}$ day between 10.00 to 11.00 hours. From each type of substrate, three places were selected by randomly and three composite samples of periphyton were taken at each of three depths $(40,80$ and $120 \mathrm{~cm}$ below the water surface)/ substrate from $2 \times 2 \mathrm{~cm}^{2}$ area. These areas were carefully scraped with a scalpel blade to remove all periphyton visually without affecting the substrate. After sampling, the substrate were placed in their original positions and marked to exclude from subsequent sampling.

The composite samples of each depth were pooled. Pooled samples from three depth of each substrate were re-suspended in $50 \mathrm{ml}$ distilled water and preserved in $5 \%$ buffered formalin in sealed container. After vigorous shaking, $1 \mathrm{ml}$ of sub sample was transferred to a Sedgewick-Rafter cell (S-R cell) divided in 1000 squares, upon which, the number of colonies was counted in 1000 squares field of chamber under binocular microscope. The periphyton sample densities were

Table 1. Types of Phyto-periphyton recorded from different natural substrates immersed in seawater earthen lined for different periods.

\begin{tabular}{|c|c|c|c|c|c|c|c|c|c|c|}
\hline \multirow{2}{*}{ S. N. } & \multirow{2}{*}{ Phyto - periphyton } & \multicolumn{3}{|c|}{15 Days } & \multicolumn{3}{|c|}{30 Days } & \multicolumn{3}{|c|}{45 Days } \\
\hline & & BP & $\mathrm{CC}$ & $\mathbf{C S}$ & BP & $\mathrm{CC}$ & $\mathbf{C S}$ & $\mathbf{B P}$ & $\mathrm{CC}$ & CS \\
\hline & Bacillariophyceae & & & & & & & & & \\
\hline 1 & Biddulphia $s p$ & + & + & + & + & + & + & + & + & + \\
\hline 2 & Chaetoceros $s p$ & + & + & + & + & + & + & + & + & + \\
\hline 3 & Coscinodiscus sp & + & + & + & + & + & + & + & + & + \\
\hline 4 & Pleurosigma sp & + & + & + & + & + & + & + & + & + \\
\hline 5 & Rhizosolenia sp & + & + & + & + & + & + & + & + & + \\
\hline 6 & Triceratium sp & + & + & - & + & + & - & - & - & - \\
\hline 7 & Nitzchia sp & + & + & + & + & + & + & + & + & + \\
\hline 8 & Leptocylindrus sp & + & + & + & + & + & + & + & + & + \\
\hline 9 & Climacosphenia sp & + & + & - & - & - & - & + & - & - \\
\hline \multirow[t]{2}{*}{10} & Gyrosigma sp. & + & + & + & + & + & + & + & + & + \\
\hline & Dinophyceae & & & & & & & & & \\
\hline 11 & Ceratium $s p$ & + & + & - & - & - & - & - & - & - \\
\hline 12 & Peridinium sp & + & + & + & + & + & - & + & - & - \\
\hline 13 & Thalassisothrix sp & + & + & + & + & + & + & + & + & + \\
\hline \multirow[t]{2}{*}{14} & Skeletonema sp & + & + & + & + & + & + & + & + & + \\
\hline & Cyanophyceae & & & & & & & & & \\
\hline 15 & Tricodesmium sp & - & + & - & + & - & - & - & - & - \\
\hline 16 & Oscillatoria & - & - & - & + & + & + & + & + & + \\
\hline
\end{tabular}

BP-Bamboo Poles, CC-Coconut Coir, CS-Coconut Shell 


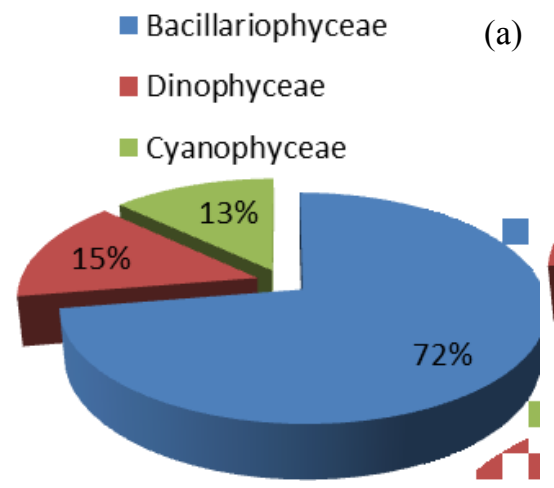
Bacillariophyceae - Dinophyceae - Cyanophyceae

(b)

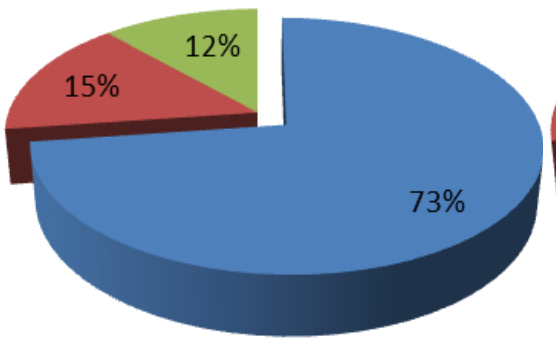

- Bacillariophyceae - Dinophyceae Cyanophyceae

Fig. 2. Phyto-periphyton composition for different natural substrates : a) Phyto-Periphyton growth on split bamboo pole, b) Phyto-Periphyton growth on Coconut coir, c) Phyto-Periphyton growth on Coconut shell.

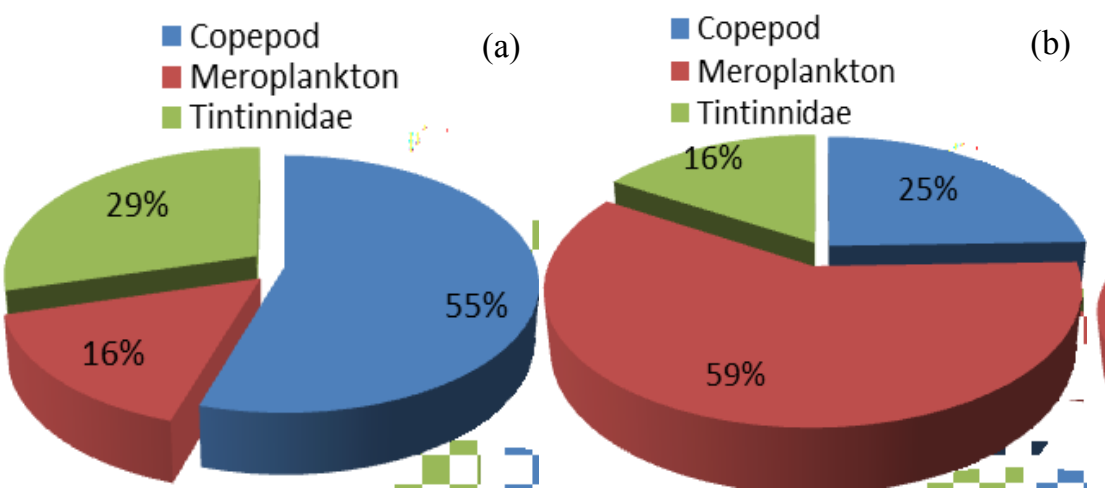

(b)

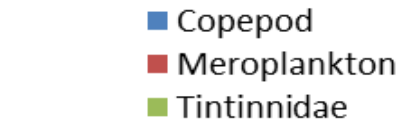

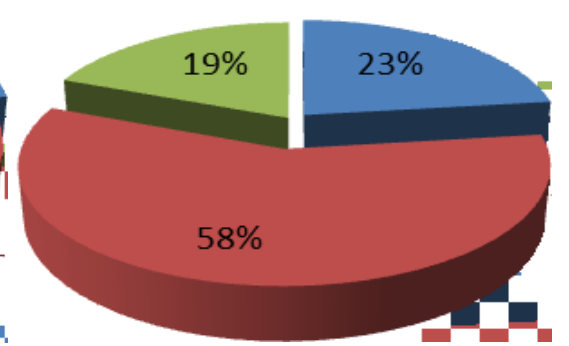

Fig. 3. Zoo-periphyton composition for different natural substrates: a) Zoo-Periphyton growth on split bamboo pole, b) ZooPeriphyton growth on Coconut coir, c) Zoo-Periphyton growth on Coconut shell.

calculated using the following formula (Equation 1) as given by Azim et al., (2002) and are given below:

$\mathrm{N}=(\mathrm{P} \times \mathrm{C} \times 100) / \mathrm{S} \quad \ldots \ldots \ldots \ldots \ldots . . . \mathrm{Eq} .1$

Where,

$\mathrm{N}=$ number of periphyton cells per $\mathrm{cm}^{2}$ surface area;

$\mathrm{P}=$ number of periphytic units counted in ten fields;

$\mathrm{C}=$ volume of final concentrate of the sample $(\mathrm{ml})$;

$\mathrm{S}=$ area of scraped surface $\mathrm{cm}^{2}$.

Taxa were identified to genus level using keys of Prescott (1962), Belcher and Swale (1976) and Belinger (1992).

Water samples were collected on biweekly basis between $10.00 \& 11.00$ am. Water quality parameters such as temperature by mercury thermometer, salinity by hand refractometer, transparency by secchi disc and $\mathrm{pH}$ by $\mathrm{pH}$ pen were measured directly from the ponds

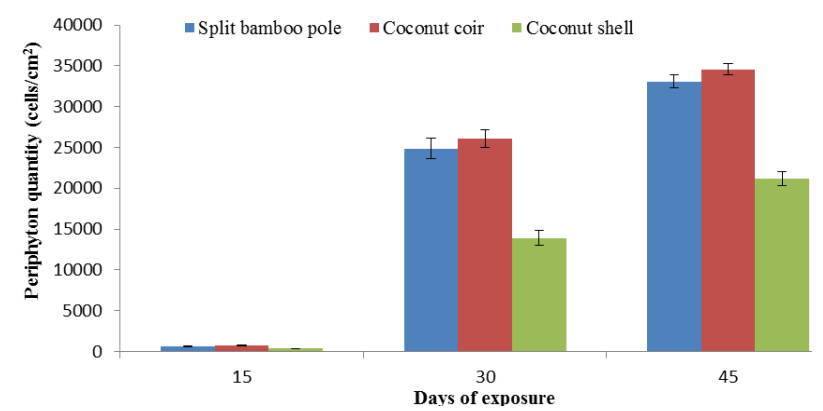

Fig. 4. Periphyton quantity for different natural substrates. and dissolved oxygen was measured following Winkler method (APHA, 1995) at lab. The water samples were filtered through GF / C Whatman glass fibre filter and the filtrate was analyzed for Nitrate-N (cadmium reduction), Nitrite-N and total ammonia nitrogen (TAN) (Phenol hypochlorite method). Non-filtered water column samples were analyzed for Chlorophyll ' a' by following standard methods as given by APHA (1995). Biological oxygen demand (5 day BOD) of water samples was estimated following APHA (1995). Data Collected from this study were analyzed statistically by One-way ANOVA, followed by Duncan's multiple range test using SPSS 20.0 and student's ' $t$ ' test using Microsoft excel.

\section{RESULTS AND DISCUSSION}

There were 16 different phyto-periphytic microalgae grew on split bamboo pole, coconut coir and coconut shell immersed in seawater of the earthen lined pond (Table 1). During experiments, the group such as Bacillariophyceae (Biddulphia, Chaetoceros, Coscinodiscus, Pleurosigma, Rhizosolenia, Triceratium, Nitzchia, Leptocylindrus, Climacosphenia, Climacosphenia); Dinophyceae (Ceratium, Peridinium, Thalassisothrix, Skeletonema) and Cyanophyceae (Tricodesmium, Oscillatoria) were observed in all the three natural substrates. Bacillariophyceae were found more on all the substrates, followed by Dinophyceae and Cyano- 
Table 2. Types of Zoo-periphyton recorded from different natural substrates immersed in seawater earthen lined for different periods.

\begin{tabular}{|c|c|c|c|c|c|c|c|c|c|c|}
\hline \multirow{2}{*}{ S.N. } & \multirow{2}{*}{ Zoo - Periphyton } & \multicolumn{3}{|c|}{15 Days } & \multicolumn{3}{|c|}{30 Days } & \multicolumn{3}{|c|}{45 Days } \\
\hline & & BP & $\mathbf{C C}$ & $\mathbf{C S}$ & BP & $\mathbf{C C}$ & CS & $\mathbf{B P}$ & $\mathbf{C C}$ & $\mathrm{CS}$ \\
\hline & Copepod & & & & & & & & & \\
\hline 1 & Acartia sp & + & - & - & + & + & + & + & + & - \\
\hline 2 & Acrocalanus sp & + & + & + & + & + & + & - & + & - \\
\hline 3 & Microsetella sp & + & + & + & + & + & - & - & - & - \\
\hline \multirow[t]{2}{*}{4} & Oithona sp & + & + & + & + & + & + & + & + & + \\
\hline & Meroplankton & & & & & & & & & \\
\hline 5 & Copepod Nauplius & + & + & + & + & + & + & + & + & + \\
\hline 6 & Spiropis Larvae & + & - & + & - & - & - & - & - & - \\
\hline 7 & Crab Zoea & + & + & + & + & + & + & + & + & + \\
\hline \multirow[t]{2}{*}{8} & Gastropod veliger & + & + & + & + & + & + & + & + & + \\
\hline & Tintinnida & & & & & & & & & \\
\hline 9 & Favella sp & + & + & + & + & + & + & + & + & + \\
\hline 10 & Tintinnopsis sp & - & - & - & + & - & - & - & - & - \\
\hline
\end{tabular}

BP-Bamboo Poles, CC-Coconut Coir, CS-Coconut Shell

phyceae. On split bamboo pole, the numbers of genera found were Bacillariophyceae (10), Dinophyceae (2), and Cyanophyceae (2) followed by Bacillariophyceae (10), Dinophyceae (2), and Cyanophyceae (2) in coconut coir and Bacillariophyceae (8), Dinophyceae (1), and Cyanophyceae (2) in coconut shell. From the result obtained, it was found that on all natural substrates, the Bacillariophyceae grew more in numbers compared to other groups (Figure $2 \mathrm{a}, 2 \mathrm{~b}$ and $2 \mathrm{c}$ ).

There were 10 different Zoo-periphyton grew on different natural substrates immersed in seawater of the earthen lined pond (Table 2). During experiments, the group Copepod (Acartia, Acrocalanus, Microsetella, Oithona); Meroplankton (Copepod Nauplius, Spiropis Larvae, Crab Zoea, Gastropod veliger) and Tintinnidae (Favella, Tintinnopsis) were observed in all the three natural substrates. Copepod were found to be more on split bamboo poles followed by Tintinnidae and Meroplankton. On coconut coir and coconut shell, Meroplankton were found more, followed by copepod and Tintinnidae. On split bamboo pole, the numbers of genera found were Copepod (4), Meroplankton (4), and Tintinnidae (2) followed by Copepod (4), Meroplankton (3), and Tintinnidae (1) in coconut coir and Copepod (4), Meroplankton (4), and Tintinnidae (1) in coconut shell. From the result, it was found that the Meroplankton grew more in numbers compared to other groups on all natural substrates (Figure $3 \mathrm{a}, 3 \mathrm{~b}$ and $3 \mathrm{c}$ ).

One way ANOVA followed by Duncan's Multiple Range Test was done for the substrates wise on periphyton quantity in terms of number for 15, 30 and 45 days of exposure period and presented in Table 3. For this, the triplicate data for each substrate from two experimental sets were pooled. Statistically, significant difference was found $(\mathrm{P}<0.05)$ in periphyton quantity among all the treatments of 15,30 and 45 days duration. The periphyton quantity from coconut coir was comparatively higher $\left(34562 \pm 671\right.$ cells $\left./ \mathrm{cm}^{2}\right)$ than the split bamboo poles $\left(33103 \pm 810\right.$ cells $\left./ \mathrm{cm}^{2}\right)$ and coconut shell $\left(21194 \pm 872\right.$ cells $\left./ \mathrm{cm}^{2}\right)$ during the final day (45) of exposure (Figure 3). The quantity of periphyton from the split bamboo pole and coconut coir during 15, 30 and 45 days sampling had no significant difference.

As per the student's ' $t$ ' test analysis of the data affirmed that highly significant was observed in periphyton quantity among all the treatments for 15, 30 and 45 days duration (Table 4). The mean values observed among all the treatments for 15, 30 and 45 days duration was given in the following descending order:

15 days

[Coconut Coir (733.833) > Spit bamboo pole $(667.5)>$ Coconut shell (340.666)]

30 days

[Coconut Coir (26117.3) > Spit bamboo pole (24860.5) $>$ Coconut shell (13888.1)]

45 days

[Coconut Coir (34562) > Spit bamboo pole (33103.5) $>$ Coconut shell (21194)]

In the present study, quantitatively, the periphyton growth was found more on coconut coir (34562 \pm 671 cells $\left./ \mathrm{cm}^{2}\right)$ than split bamboo poles $(33103 \pm 810$ cells $\left./ \mathrm{cm}^{2}\right)$ and coconut shell $\left(21194 \pm 872\right.$ cells $\left./ \mathrm{cm}^{2}\right)$

Table 3. Periphyton quantity (Number of cells $/ \mathrm{cm}^{2}$ ) of different substrates immersed in seawater earthen lined pond for different periods.

\begin{tabular}{llll}
\hline Days of exposure & Split bamboo poles & Coconut coir & Coconut shell \\
\hline 15 & $667 \pm 58^{\mathrm{a}}$ & $733 \pm 68^{\mathrm{a}}$ & $340 \pm 43^{\mathrm{b}}$ \\
30 & $24860 \pm 1250^{\mathrm{a}}$ & $26117 \pm 1083^{\mathrm{a}}$ & $13888 \pm 901^{\mathrm{b}}$ \\
45 & $33103 \pm 810^{\mathrm{a}}$ & $34562 \pm 671^{\mathrm{a}}$ & $21194 \pm 872^{\mathrm{b}}$ \\
\hline
\end{tabular}

Values are expressed as (Mean $\pm \mathrm{SE}$ ), Values with same superscripts in a row do not differ significantly at $\mathrm{P}>0.05$. $(\mathrm{n}=6)$ 
Table 4. Student's t-test analysis of the data relating to periphyton quantity for different natural substrates.

\begin{tabular}{|c|c|c|c|c|c|c|c|c|}
\hline S. N. & $\begin{array}{l}\begin{array}{l}\text { Parameters } \\
\text { (Substrate) }\end{array} \\
\end{array}$ & $\begin{array}{l}\begin{array}{l}\text { Exposure } \\
\text { (days) }\end{array} \\
\end{array}$ & $\mathbf{X}_{1}$ & $\mathbf{X}_{2}$ & DF & $\begin{array}{l}\text { Student's } \\
\text { t value } \\
\end{array}$ & P Value & LS \\
\hline 1 & SBP x CC & 15 & 667.5 & 733.833 & 2 & -3.02918 & $\mathrm{P} \geq 0.04$ & $\mathrm{~S}$ \\
\hline 2 & SBP $\times C C$ & 30 & 24860.5 & 26117.3 & 2 & -3.26809 & $P \geq 0.04$ & $\mathrm{~S}$ \\
\hline 3 & SBP x CC & 45 & 33103.5 & 34562 & 2 & -6.92197 & $\mathrm{P} \geq 0.01$ & $\mathrm{~S}$ \\
\hline 4 & $\mathrm{CC} \times \mathrm{CS}$ & 15 & 733.833 & 340.666 & 2 & 9.156971 & $P \geq 0.005$ & $\mathrm{~S}$ \\
\hline 5 & $\mathrm{CC} \times \mathrm{CS}$ & 30 & 26117.3 & 13888.1 & 2 & 28.91941 & $P \geq 0.0005$ & $\mathrm{~S}$ \\
\hline 6 & $\mathrm{CC} \times \mathrm{CS}$ & 45 & 34562 & 21194 & 2 & 36.36932 & $P \geq 0.0003$ & $\mathrm{~S}$ \\
\hline 7 & SBP $x$ CS & 15 & 667.5 & 340.666 & 2 & 15.4871 & $\mathrm{P} \geq 0.002$ & S \\
\hline 8 & SBP $\times$ CS & 30 & 24860.5 & 13888.1 & 2 & 19.18891 & $\mathrm{P} \geq 0.001$ & $\mathrm{~S}$ \\
\hline 9 & SBP $\times$ CS & 45 & 33103.5 & 21194 & 2 & 75.8948 & $8.68 \mathrm{E}-05$ & $\mathrm{~S}$ \\
\hline
\end{tabular}

SBP - Split Bamboo Poles, CC - Coconut Coir, CS - Coconut Shell, LS - Level of Significance, DF - Degrees of freedom

in the final day of the experiment (Figure 4). The quantity of periphyton varied significantly with substrate type, fertilization level, environment conditions and taxonomic composition (Makarevich et al., 1993 and Keshavanath et al., 2001). Keshavanath et al. (2012) made the Periphyton growth comparison study for four natural substrates such as bamboo mat, sugarcane bagasse, coconut leaf and palm leaf and reported that the periphyton growth was better on coconut leaf than other tested materials. These reports are similar to the present study. Dutta et al. (2013) compared the substrate palm leaf and nylon net for periphyton growth and found that the palm leaf had better periphyton growth than nylon net. The substrates from organic origin attract more periphytic growth on them. Amisah et al. (2008) and Saikia and Das (2011) compared the biodegradable and non-biodegradable substances for periphyton based aquaculture to enhance fish production. They reported about 88 genera of periphytic microalgae composed of Chlorophyceae, Bacillariophyceae and Cyanophyceae. Chlorophyceae and Cyanophyceae preferred rice stems, where as, Bacillariophyceae preferred glass slide. In the present study, a total 16 genera were found and among them the Bacillariophyceae preferred natural substrates (split bamboo pole, coconut coir and coconut shell) for its growth and settlement in seawater medium in the earthen lined pond. Increasing the nutrient levels and using substrates that help to periphyton growth seem to be possible solution to enhance fish production in periphyton-based pond aquaculture system (Azim et al., 2004 and Keshavnath et al., 2002). According to Azim et al. (2001), microbial organisms and meiomacrofauna grown in the periphyton may also be utilized by cultured organism and therefore, the need for artificial feed can be substantially reduced by providing the substrates in aquaculture ponds.

The mean and standard deviation of various physicochemical water quality parameters recorded are given in Table 5. In the periphyton experimental pond, temperature, salinity, $\mathrm{pH}, \mathrm{BOD}$, nitrite and ammonia did not show significant difference $(\mathrm{P}>0.05)$ over the experimental period while secchi disk reading, dissolved oxygen, nitrate and chlorophyll 'a' were shown significant difference $(\mathrm{P}<0.05)$ over the experimental period (Table 5). The highest secchi disk reading was observed on $15^{\text {th }}$ day $(53.00 \pm 1.41 \mathrm{~cm})$, while, it was lowest in the final day $(47.00 \pm .00 \mathrm{~cm})$. The lowest and highest dissolved oxygen was recorded on $15^{\text {th }}$ day and final day were $5.76 \pm 0.22 \mathrm{mg} / 1$ and $6.80 \pm 0.34$ $\mathrm{mg} / 1$ respectively. This level shows the good sign of dissolved oxygen in the pond and provide good environment for shrimp culture. Significantly higher value of Nitrate- $\mathrm{N}$ was observed on $45^{\text {th }}$ day $(0.41 \pm 0.02$ $\mu$ g.at. $\left.\mathrm{NO}_{3}-\mathrm{N} / 1\right)$, while, it was lower on $15^{\text {th }}$ day $(0.33$ $\pm 0.01 \mu$ g.at. $\left.\mathrm{NO}_{3}-\mathrm{N} / 1\right)$ of the experiment. With regard to chlorophyll ' $a$ ', significant higher values were observed in the final day $\left(75.25 \pm 5.89 \mathrm{mg} / \mathrm{m}^{3}\right)$ and it was lower on $15^{\text {th }}$ day $\left(40.50 \pm 9.98 \mathrm{mg} / \mathrm{m}^{3}\right)$ of the experiment. On the contrary, the biological oxygen demand (BOD) showed variations among the sampling days and this would manifest the differential rates of consumption pattern of oxygen by the organisms over the experimental period. Several studies proved the

Table 5. Physico-chemical parameters of seawater earthen lined pond during experimental period.

\begin{tabular}{lccc}
\hline Water Parameters & $\mathbf{1 5}$ days & 30 days & 45days \\
\hline Transparency $(\mathrm{cm})$ & $53.00 \pm 1.41^{\mathrm{a}}$ & $48.50 \pm .70^{\mathrm{b}}$ & $47.00 \pm .00^{\mathrm{b}}$ \\
Water Temperature $\left({ }^{\circ} \mathrm{C}\right)$ & $32.00 \pm .00^{\mathrm{a}}$ & $32.00 \pm .00^{\mathrm{a}}$ & $33.00 \pm .00^{\mathrm{a}}$ \\
Salinity $(\mathrm{ppt})$ & $40.00 \pm .00^{\mathrm{a}}$ & $42.00 \pm .00^{\mathrm{a}}$ & $43.00 \pm .00^{\mathrm{a}}$ \\
$\mathrm{pH}$ & $7.85 \pm .05^{\mathrm{a}}$ & $7.80 \pm .00^{\mathrm{a}}$ & $7.85 \pm .05^{\mathrm{a}}$ \\
Dissolved Oxygen $(\mathrm{mg} / \mathrm{l})$ & $5.76 \pm .22^{\mathrm{a}}$ & $6.00 \pm .34^{\mathrm{ab}}$ & $6.80 \pm .34^{\mathrm{b}}$ \\
BOD $(\mathrm{mg} / \mathrm{l})$ & $2.32 \pm .34^{\mathrm{a}}$ & $2.24 \pm .27^{\mathrm{a}}$ & $2.88 \pm .27^{\mathrm{a}}$ \\
Nitrite $\left(\mu \mathrm{g} \cdot a t . \mathrm{NO}_{2}-\mathrm{N} / \mathrm{l}\right)$ & $0.47 \pm .08^{\mathrm{a}}$ & $0.45 \pm .07^{\mathrm{a}}$ & $0.46 \pm .04^{\mathrm{a}}$ \\
Nitrate $\left(\mu \mathrm{g} \cdot a t . \mathrm{NO}_{3}-\mathrm{N} / \mathrm{l}\right)$ & $0.33 \pm .01^{\mathrm{b}}$ & $0.34 \pm .01^{\mathrm{b}}$ & $0.41 \pm .02^{\mathrm{a}}$ \\
Ammonia $\left(\mu \mathrm{g} \cdot \mathrm{at} \cdot \mathrm{NH}_{3}-\mathrm{N} / \mathrm{l}\right)$ & $0.29 \pm .02^{\mathrm{a}}$ & $0.30 \pm .0^{\mathrm{a}}$ & $0.31 \pm .01^{\mathrm{a}}$ \\
Chlorophyll 'a' $\left(\mathrm{mg} / \mathrm{m}^{3}\right)$ & $40.50 \pm 9.98^{\mathrm{b}}$ & $61.21 \pm 8.64^{\mathrm{ab}}$ & $75.25 \pm 5.89^{\mathrm{a}}$ \\
\hline
\end{tabular}

Values are expressed as (Mean \pm SD), Values with same superscripts in a row do not differ significantly at $P>0.05$. $(n=2)$ 
reduction of BOD level in substrate installed tanks compared to non substrates tank (Ramesh et al., 1999; Umesh et a1., 1999; Keshavanath et al., 2001, 2002, 2004; Dharmaraj et al., 2002; Mridula et al., 2003). In the present study also, the BOD values were low in the substrate added pond and this finding which fully concurs with the above workers findings. Results of the ANOVA showed that significant variations were observed in the Nitrate- $\mathrm{N}$ and chlorophyll ' $\mathrm{a}$ ' concentrations over the experimental period. In ponds and lakes, phytoplankton productivity is positively correlated with nutrient concentrations (Boyd, 1990) and in periphyton based ponds, this relationship is interfered with by competition and interactions between periphyton and phytoplankton. Higher chlorophyll 'a' content in substrates treatment indicates the phytoplankton production, which is an indication of the positive effect on plankton nutritional quality (Azim et al., 2002).

\section{Conclusion}

The present experiment for periphyton growth on natural substrates has shown that the coconut coir has the potential for better periphyton growth on them than the split bamboo pole and coconut shell in earthen lined pond seawater medium. Periphyton substrates do not have any adverse effect on water quality parameters. The present experiment for periphyton growth also exhibiting substrates - periphyton - environment relationship. Periphyton grown on the natural substrate is an important natural food source and the quantity of artificial feed can be reduced substantially for the fishes in aquaculture system. More research is needed to determine optimum substrate density and fertilization strategies and to select the fish species combinations that achieve the highest production.

\section{ACKNOWLEDGEMENTS}

The authors are thankful to the University Grant Commission (UGC), New Delhi for providing financial support. The authors are grateful to Dean, Fisheries College and Research Institute, Thoothukudi for providing facilities and encouragement.

\section{REFERENCES}

Amisah, S., Adjei-Boateng, D. and Afianu, D. D.(2008). Effects of bamboo substrate and supplementary feed on growth and production of the African catfish, Clarias Gariepinus J Appl Sci Environ Mana., 12(2): 25 - 28.

APHA (1995). Standard Methods for the Examination of the Water and Wastewater. American Public Health Association, Washington.

Arnold, S. J., Sellars, M. J., Crocos, P. J. and Coman, G. J. (2006). Intensive production of juvenile tiger shrimp Penaeus monodon: An evaluation of stocking density and artificial substrates. Aquaculture, 261: 890-896.

Avnimelech, Y., Verdegem, M.C.J., Kurup, M. and Keshavanath, P. (2008). Sustainable land-based aquaculture: rational utilization of water, land and feed resources.
Medit. Aquacult. J., 1:45-55.

Azim, M. E., Verdegem, M. C. J., Mantingh, I., van Dam, A. A. and Beveridge, M. C. M. (2003). Ingestion and utilization of periphyton grown on artificial substrates by Nill tilapia Oreochromis niloticus. L. Aquac. Res., 34: 85-92.

Azim, M. E., Wahab, M A., Van Dam, A. A., Beveridge, M. C. M. and Verdegem, M. C. J. (2001). The potential of periphyton-based culture of two Indian major carps, rohu Labeo rohita (Hamilton) and gonia Labeo gonius (Linnaeus). Aquacult. Res., 32: 209-216.

Azim, M. E., Wahab, M. A., Biswas, P. K., Asaeda, T., Fujino,T. and Verdegem, M.C.J. (2004). The effect of periphyton substrate density on production in freshwater polyculture ponds. Aquaculture, 232: 441- 453.

Azim, M. E., Wahab, M. A., Verdegem, M. C. J., van Dam, A. A., van Rooij, J. M., Malcolm, M. E. and Beveridge, C. M. (2002). The effects of artificial substrates on freshwater pond productivity and water quality and the implications for periphyton-based aquaculture. Aquat. Living Resour., 15: 231-241.

Ballester, E. L. C., Waisielesky, W. J., Cavalli, R. O. and Abreu, P. C. (2007). Nursery of the pink shrimp Farfantepenaeus paulensis in cages with artificial substrates: Biofilm composition and shrimp performance. Aquaculture, 269: 355-362.

Belcher, H. and Swale, S. (1976). A Beginner's Guide to Freshwater Algae. Institute of Terrestrial Ecology. Natural Environmental Research Council, London.

Belinger, E.G. (1992). A Key to Common Algae. The Institute of Water and Environmental Management, London, UK.

Boyd, C. E. (1990). Water Quality in Ponds for Aquaculture. Birmingham Publishing Company, Birmingham, Alabama. $482 p$.

Burford, M. A., Sellars, M. J., Arnold, S. J., Keys, S. J., Crocos, P. J. and Preston, N. P. (2004). Contribution of the natural biota associated with substrates to the nutritional requirements of the post-larval shrimp, Penaeus esculentus (Haswell), in high-density rearing systems. $A q$ uac. Res., 35: 508-515.

Dharmaraj, M., Manissery, J. K. and Keshavanath, P. (2002). Effects of biodegradable substrate, sugercase bagasse and supplemental feed on growth and production of fringed - liped peninsula carp, Labeo fimbriatus (Bloch), Acta Ichthyologica et piscatorial, 32:137-144.

Dutta, M. P., Phukan, B., Baishya, S., Hussain, I. A., Kashyap, D., Deka, P. and Roy, S. (2013). Comparative study of periphyton growth on two different substrates (palm leaf and nylon net). Environment and Ecology, 31 (4): 1725-1731.

Keshavanath, P., Gangadhar, B., Ramesh, T. J., van Dam, A. A., Beveridge, M. C.M. and Verdegem, M. C. J. (2004). Effects of bamboo substrate and supplemental feeding on growth and production of hybrid red tilapia fingerlings (Oreochromis mossambicus x Oreochromis niloticus). Aquaculture, 235: 303-314.

Keshavanath, P., Gangadhar, B., Ramesh, T. J., Van Rooij, J. M. Beveridge, M. C. M., Baird, D. J., Verdegem, M. C. J. and Van Dam, A. A. (2001). Use of articicial substrates to enhance production of freshwater herbivorous fish in pond culture. Aquacult. Res. 32: 189-197.

Keshavanath, P., Gangadhar, p., Ramesh, T. J., van Dam, A. 
A., Beveridge, M.C. M. and Verdegem, M. C. J. (2002). The effects of periphyton and feeding on the production of the indigenous carps Tor khudree and Labeo fimbriatus in tanks with different bamboo substrate densities. Aquaculture, 213:207-218.

Keshavanath, P., Manissery, J. K., Ganapathibha, A. and Gangadhar, B. (2012). Evaluation of Four Biodegradable Substrates for Periphyton and Fish Production Journal of Applied Aquaculture, 24: 60-68.

Makarevich, P. R., Larionov, V. V. and Druzhkov, N. V. (1993). Mean weights of dominant phytoplankton species of the Barents sea, Algology, 3(1): 103-106.

Mridula, R, Manissery, J. K., Keshavanath, P., Shankar, K. M., Nandeesha, M. C. and Rajash, K.M. (2003). Water quality, biofilm production and growth of fringed lipped carp (Labeo fimbriatus) in tanks provided with two solid substrates, Bioresource Technology, 87(3): 263-267.

Prescott, G.W. (1962). Algae of the Western Great Lakes Area. Wm. C. Brown Co., Inc., Dubuque, lowa, 977 pp.

Preto, A. L., Cavalli, R., Pissetti, T. Abreu, P. C. and Wasielesky, W. J. (2005). Effect of stocking density on the biofilm and the performance of post-larvae Farfan- tepenaeus paulensis cultured in cages. Cienc Rural, 35: 1417-1423 (in Portuguese).

Ramesh, M. R., Shankar, K.M., Mohan, C.V. and Varghese, T. J. (1999). Comparison of three plant substrates for enhancing carp growth through bacterial biofilm. Aquac. Eng. 19: 119-131.

Saikia, S. K. and Das, D. N. (2011). Diversity and productivity (Chlorophyll-a and Biomass) of periphyton on natural and artificial substrates from wetland ecosystem. Journal of Wetlands Ecology, 5: 1-9.

Saikia, S.K., Majumder, S., Nandi, S. and Saha, S.K. (2013). Feeding ecology of the freshwater fish rohu, Labeo rohita (Hamilton 1822): a case of intelligent feeding in the periphyton-based environment. Zoology and Ecology, 23: 266-274.

Umesh, N. R., Shankar, K. M. and Mohan, C. V. (1999). Enhancing growth of common carp, rohu and Mozambique tilapia through plant substrate: the role of bacterial biofilm. Aquac. Int., 7: 251-260.

Zarain-Herzberg, M., Campa-Córdova, A.I. and Cavalli, R. O. (2006). Biological viability of producingwhite shrimp Litopenaeus vannamei in seawaterfloating cages. Aquaculture, 259: 283-289. 